\title{
TWO DECADES OF ELECTION OBSERVATION BY THE AFRICAN UNION: A REVIEW
}

\section{Chika Charles Aniekwe and Samuel Mondays Atuobi}

Chika Charles Aniekwe is a former Senior Political/Election Officer at the Democracy and Electoral Assistance Unit, Department of Political Affairs, African Union Commission. ${ }^{1}$ email: Chikacharles@gmail.com

Samuel M. Atuobi is a Senior Political / Election Officer at the Democracy and Electoral Assistance Unit, Department of Political Affairs, African

Union Commission. ${ }^{1}$

email: Atuobis@yahoo.com

\begin{abstract}
Between 1989 and 2013, the African Union (AU) observed 423 elections in Africa. However, these election observation missions were inconsistent at best in terms of approach, methodology, framework and status. The first, which was in Namibia in 1989, was deployed within the framework of the United Nations (UN) statute in terms of which the UN invited the AU. The subsequent election observation missions have to date been deployed either as diplomatic or mediation missions or a combination of diplomatic and independent technical missions. This article shows that the election observation journey of the AU has passed through several stages and regimes. While we recognise the challenges, we also point towards improvement, and identify the missing links that the AU needs to complete to become a truly independent actor in its election observation missions.
\end{abstract}

Keywords: African Union, democracy, elections, election observation

1 Views and opinions expressed in this article are entirely the authors' and do not represent that of the African Union Commission. 


\section{INTRODUCTION}

This article examines the various phases the African Union Election Observation Missions (AUEOMs) have passed through since participation by the Organisation of African Unity $\mathrm{OAU}^{2}$ in the UN-led mission to monitor Namibia's referendum in 1989. This historical analysis includes a close examination of the approaches, methods and lessons that can be drawn from the gradual but consistent development of AUEOM methodology. Starting with an overview of the democratic development in post-Cold War Africa, we examine the struggle to end colonialism and the participation of the continental organisation in ending apartheid and occupation. We proceed by drawing a link between the end of colonisation, occupation and apartheid and the development of instruments that form shared African values and norms in democracy, political rights and freedoms. Further attention is given to the changing nature of election observation in Africa by the OAU / AU, from a political-cum-diplomatic mission to an independent and technical mission. This leads into a critical examination of the changing framework from the short-term election observation mission to a long-term observation mission based on the electoral cycle approach. Finally, the article explores and illuminates the progress that has been made thus far, before highlighting areas for further development and improvement.

The end of the Cold War over two decades ago signifies two important developments in world history. It marked the end of nuclear proliferation and the arms race between the two major powers, the United States of America (USA) and the former United Soviet Socialist Republic (USSR). The second development, proceeding from the first, is the spread of democracy in most countries in Africa and Eastern Europe. The 1990s were particularly impressive for Africa as many authoritarian regimes accepted constitutional law, and the spread of democracy

2 On May 251963 in Addis Ababa, Ethiopia, the 32 African states that had achieved independence at that time agreed to establish the Organization of African Unity (OAU). A further 21 members joined gradually, reaching a total of 53 by the time of the AU's creation in 2002. On 9 July 2011, South Sudan became the 54th African Union (AU) member.

The OAU's main objectives, as set out in the OAU Charter, were to promote the unity and solidarity of African states; coordinate and intensify their cooperation and efforts to achieve a better life for the peoples of Africa; safeguard the sovereignty and territorial integrity of Member States; rid the continent of colonialism and apartheid; promote international cooperation within the United Nations framework; and harmonise members' political, diplomatic, economic, educational, cultural, health, welfare, scientific, technical and defence policies.

The OAU operated on the basis of its Charter and the 1991 Treaty Establishing the African Economic Community (known as the Abuja Treaty). Its major organs were the Assembly of Heads of State and Government, Council of Ministers and the General Secretariat as well as the Commission of Mediation, Conciliation and Arbitration; Economic and Social Commission; Educational, Scientific, Cultural and Health Commission; and Defence Commission. The Commission of Mediation, Conciliation and Arbitration was replaced by the Mechanism for Conflict Prevention, Management and Resolution in 1993. For more information, visit History of The OAU \& AU at http: / / www.au.int/ en/history/oauand-au 
and popular participation across different regions of Africa gained momentum. During this period, apartheid ended in South Africa, there was popular rejection of military rule in Nigeria, and many other African countries entered a new trajectory towards democracy. This included the fall of Samuel Doe in Liberia and Mathieu Kerekou in Benin (Fayemi 2009). A new democratic wave thus began to spread across Africa. As a result, multiparty politics led to several elections in different countries.

African countries have continued to implement different electoral systems while there is a growing consensus and recognition that democracy is a lesser evil in terms of political ideology and systems. It needs to be mentioned that attempts to establish multiparty democracy in some African countries have met with resistance from the ruling class, resulting in civil conflict and political instability. Civil conflicts broke out in Somalia, Liberia, Sierra Leone, and the Democratic Republic of Congo (then Zaire).

The acceptance of democracy in Africa after the Cold War is reflected in the recognition by the then continental body, the OAU, of the need to move beyond the struggle against colonialism towards the democratisation of Africa ${ }^{3}$. This determination was reinforced by its role in ending apartheid in South Africa and the occupation of Namibia by South Africa. The OAU's decision to participate in the referendum of Namibia in 1989 served both to show support and as a statement of intent in ensuring that procedure as contained in the UN mandate was followed. The decision to participate was also rooted in a change in mindset to ensure that Namibia's referendum was democratic and inclusive. The renewed intensity of the OAU towards the liberation of South Africa served also to underscore its commitment to end colonialism and move towards freedom and democracy. At the Declaration and Resolution adopted at the Twentieth Ordinary Session of the Assembly of Heads of State and Government in Addis Ababa, Ethiopia on 12-15 November 1984, the OAU set the tone for a democratic Africa. In Paragraph 7 , it stated that South Africa and Namibia cannot be excluded from freedom (OAU 1984).

The 1990s was a decade of mixed fortune for Africa. While democracy was gaining root in Africa, dictatorship was breeding side-by-side, thus restricting the regime change that the OAU had envisaged. There were coups d'état across Africa - including in Nigeria, The Gambia and Sierra Leone. The incessant coups d'état and apparent disrespect for constitutionally elected government in Africa moved the OAU to reject any unconstitutional change as unacceptable, anachronistic and contradictory to the organisation's commitment to promote democratic principles

3 It is worth remembering that previous OAU declarations and decisions regarding colonial rule and domination have referred to democracy through a consistent call for freedom and self-determination. 
and conditions (OAU 1999). Pursuant to this declaration, the OAU reviewed the state of democracy on the continent and committed itself to the principle of promoting democracy and condemning coups d'état in a declaration signed in Lomé, Togo, in July 2000. This included a set of common values and principles for democratic governance, a definition of what constitutes unconstitutional change, the development of measures and actions that the OAU would progressively take to respond to an unconstitutional change of government, and an implementation mechanism (OAU 2000).

Further steps were taken during the Lomé Summit with the establishment of the African Union (AU) through the Constitutive Act. The promotion of democratic principles and institutions, popular participation and good governance were clearly articulated in Article 3(g) of this Act (AU 2000). ${ }^{4}$ Pursuant to the new shift in focus from liberation to democratisation, in 2002 the AU adopted the Declaration on the Principles Governing Democratic Election in Africa; the socalled Durban Declaration (AU 2002b). To ensure that those principles constituted a guiding norm for the African democratic process, member states agreed to monitor elections in Africa as one way of ensuring compliance. In doing so, the heads of states and government took further action by embedding election observation and monitoring as part of the AU's monitoring of member states' commitment to democratisation. This was in accordance with the set principles as contained in the Durban Declaration, by developing Guidelines for African Union Electoral Observation and Monitoring Missions (AU 2002a). These instruments were given further impetus in 2007 with the African Charter of Democracy, Election and Governance (AU 2007). Together these instruments have defined and guided the AU's effort to democratise Africa. However, the implementation of the provisions of the various instruments with regard to election observation has been gradual and in some cases elusive.

\section{FROM NAMIBIA TO DURBAN: \\ DEVELOPMENT OF AU INSTRUMENTS ON DEMOCRACY AND ELECTIONS}

With the upsurge of multiparty elections in Africa in the late 1980s and early 1990s came the need to have neutral arbiters, particularly from the international community, to observe the extent to which elections conformed to national and international norms. This was also necessary for the consolidation of democracy as most African countries were transitioning from one-party or military dictatorships 
to multiparty democracies. This period also marked the end of decolonisation with the independence of Namibia in 1989 and the end of apartheid in 1994.

One of the responses adopted by the OAU to democratic process in Africa during this period was that of election observation. This began in Namibia in 1989 and evolved into regular election observation missions in their current form by the AU. The nature and form of election observation by the AU from the 1990s will be dealt with in the next sections. In this section, the focus is on how the OAU gradually developed the normative basis for election observation. This was through what we consider to be normative pronouncements or declarations to binding norms that underpin election observation and democratic practices today. Some key normative declarations will be discussed before the binding norms.

The earliest such declaration was the Declaration on the Political and Socio-economic Situation in Africa and the Fundamental Changes Taking Place in the World, adopted in 1990 (OAU 1990). This document took cognisance of developments not only in Africa but also in the world, and the need for African countries to respond positively. In this sense, African leaders signified their readiness to go along with the new political and democratic dispensations in the world, and accepted the need to open up the democratic space for multiparty democracy (ibid). The document thus endorsed demands by social forces for political changes and further underlined the OAU's resolve for democracy to spread in Africa ${ }^{5}$ (OAU 1997).

There was a new milestone following the overthrow of Ahmed Tejan Kabbah in Sierra Leone on 25 May 1997. The OAU under the leadership of Secretary General Salim Ahmed Salim pushed not only for the rejection of unconstitutional changes in government, but also for the non-recognition of any government that came into power through such means, both within and outside Africa (Tieku 2009). Salim also pushed for such states whose governments came into power unconstitutionally to be excluded from participating in the Union's activity (OAU 1998). These resolutions and policy statements culminated in the adoption of the Declaration on Unconstitutional Changes of Government in Algiers in 1999 (OAU 1999).

This declaration was unprecedented on the continent in that it was based on the recognition that unconstitutional changes of government were inimical to and detracted from the consolidation of democracy on the continent. To place this in its proper context, a number of military takeovers had taken place on the continent

5 During its Heads of States and Government Summit in Harare in 1997, the OAU called for a more democratic world including the reforming of the Security Council in a democratic manner. It recommended in its decision and declarations the expansion of the numbers of the permanent members of the Security Council to reflect the new and emerging trends in the world, especially the inclusion of members from the African continent. 
in the 1990s in defiance of the prevailing notions that democratic governance or constitutional rule was a continental agenda. In reality, what the above declaration sought was to communicate clearly to member states of the OAU and to the world that the OAU, and indeed African states, would not accept frustrations with the ongoing democratic dispensation and were committed to democratic processes. It also sought to reassure sitting presidents and governments that the OAU would support any democratically constituted government who faced armed resistance. Ironically, this meant that sitting military governments who feared resistance also sought cover under this guise while tinkering with the democratic future of their countries. The Algiers declaration discussed above was reinforced a year later by the 2000 Lomé Declaration for an OAU response to unconstitutional changes of government.

While the Algiers declaration was aimed at communicating the rejection of unconstitutional changes of government, the Lomé Declaration was principally about what to do in cases of unconstitutional change of government. This included: (a) intervention by mercenaries to replace a democratically elected government; (b) replacement of democratically elected governments by armed dissident groups and rebel movements; and (c) the refusal by an incumbent government to relinquish power to the winning party after free, fair and regular elections (OAU 1999; OAU 2000; Souaré 2009). The document went further by articulating the form of sanction to be imposed on member states that violated the declaration, including public condemnation and suspension until constitutional order is restored.

The documents therefore strengthen the resolve to provide closure to all forms of unconstitutional changes of government. Since then the OAU, and now the AU, has consistently denounced coups d'état in member states, imposed sanctions and worked towards the restoration of constitutional order. However, critics question the extent of AU application of the norm and argue that the application has been selective at best from one country to another. Souaré (2014) argues that the selective application of the norm relates to conceptual inconsistency in the application of the norms, as well as the failure to understand and interpret consistently the factors that constitute unconstitutional changes of government and the rationale for application. However, the suspension in 2013 of the membership of Egypt, one of the 'big five', shows a step forward in the Union's resolve to attempt consistency in applying the rule. The resolve of the AU through the International Contact Group on Madagascar (ICG-M) in ensuring that article $25(4)^{6}$ of the African Charter on Democracy, Elections and Governance is respected, points to a new direction regarding consistency in norm application as argued by (Souaré 2014).

6 Article 25(4) states that the perpetrators of an unconstitutional change of government shall not be allowed to participate in elections held to restore the democratic order or hold any position of responsibility in political institutions of their state. 


\section{From Rejection of Unconstitutional Changes of Government to Development of Appropriate Election Observation Instruments}

While regular elections were gaining ground all over the continent and were increasingly observed by the AU and other international election observation groups, the elections in most cases fell short of acceptable standards. Yet there were no frameworks on the continent with which to measure electoral standards. To fill this gap, the AU developed a more precise, elections-focused document, the Durban Declaration on Principles Governing Democratic Elections in Africa (AU 2002b). This document focused on certain key principles or standards that democratic elections must meet, and actions that states must undertake to actualise the standards. With reference to the principles articulated in the declaration, it states 'democratic elections are the basis of the authority of any representative government'. It further states that elections are essential for good governance, the rule of law, the maintenance and promotion of peace, security, and stability; and democratic elections are a key element in conflict prevention, management and resolution (AU 2002b). An important aspect of the principles is that they set a yardstick for democratic elections to be free and fair, guided by democratic constitutions and appropriate legal framework, held at regular intervals, and inclusive (AU 2002a). We argue that this yardstick provides the standard with which the AU observes elections.

A complementary document to the Declaration is the African Union Guidelines for Elections Observation and Monitoring Missions of 2002, which provided comprehensive guidelines for election observation activities by the African Union Commission (AU 2002a). The guidelines define election observation as 'gathering information and making an informed judgment', and monitoring as 'the authority to observe an election process and to intervene in the process if relevant laws or standard procedures are being violated'. The guidelines also provided definitions for assessment. The document further provides criteria for determining the nature and scope of AU observation and monitoring; the mandates, rights and responsibilities of AU election observers and monitors; and a detailed code of conduct for AU election observers and monitors (ibid). Another landmark endorsement of the OAU's involvement in election observation was during the $64^{\text {th }}$ Session of the Council of Ministers in July 1996, in Yaoundé, Cameroon. The session, in its deliberations on the Report of the Secretary General on the Process of Election Monitoring by the OAU, called for the OAU to assume greater responsibility in the democratisation process in Africa, including election observation.

While these declarations were useful for the purpose of supporting democratic consolidation and marked a departure from the pre-1990s period when 
military rule and dictatorship were the order of the day, they did not go far enough. The argument here is that no country could be held accountable for disrespect towards these declarations. However, we believe that this document informed the subsequent development of more binding regimes or documents such as the Charter, and treaties that countries have to adopt, sign, ratify and take steps to domesticate. Compared with declarations, member states can be held accountable for charters and treaties acceded to. Some of these binding documents include the Constitutive Act of the African Union; the Peace and Security Council Protocol; and the African Charter on Democracy, Elections and Governance. In terms of formality, the most important document on democracy, elections and governance is the African Charter on Democracy, Elections and Governance (AU 2007). It calls for the building of democratic institutions in a manner that supports the organisation of free, fair and transparent elections. The Charter has therefore become one of the key reference points for election observations in Africa.

\section{THE CHANGE IN APPROACH: FROM DIPLOMATIC TO INDEPENDENT AND TECHNICAL MISSIONS}

Election observation missions are largely regarded as a technical activity, albeit with obvious political necessity. This is because in addition to undertaking a technical assessment of how an election process is managed, there is always the need for these missions to manage political tensions. This is especially true in African where there is high correlation between elections and the outbreak of conflict. Thus the AU as a continental body has always approached election observation with a 'preventive diplomacy' approach to avert the possible outbreak of conflict. In particular, the role of the head of mission in AUEOMs includes undertaking diplomatic activities to prevent the possible outbreak of electoral violence and conflict. This is equally true for other election observation missions undertaken by regional bodies like the Economic Community of West Africa States (ECOWAS) and the Southern African Development Community (SADC). Nevertheless, finding an important balance between the technical aspect of a mission and its political dimension is necessary for a successful mission. In the early stages of AUEOMs, observer teams comprised mainly career diplomats who might have observed electoral processes through diplomatic and political lenses. An exception was the OAU observation in Namibia, which was to fulfil United Nations Security Council Resolution 435 on the independence of Namibia and was a largely diplomatic activity. Until the operational establishment of the Democracy and Electoral Assistance Unit (DEAU) in 2008, AUEOMs lacked 
technical elements. Most AU observers consisted of a team of diplomats from different countries. In fact, priority was given to conflict prevention rather than technical observation.

With the establishment of the DEAU, the AU started to put in place a structured process of recruiting and training observers. Observers are trained using AU election observation methodology, international and AU instruments on election observation, the code of conduct for election observers, and how to use an AU election observation checklist for gathering data. Each AUEOM also includes a technical team from the African Union Commission, the Pan-African Parliament and partner institutions such as the Electoral Institute for Sustainable Democracy in Africa (EISA). This team provides technical support for observers in data gathering, analysis and reporting. This approach underlines the AUEOM's focus on the technical aspect of elections while retaining some level of diplomatic or political representation. Currently, a typical AUEOM is composed of election experts from election management bodies, human rights groups and the civil society organisations (CSOs) who are engaged in electoral processes in their various countries and regions. These groups will always constitute more than $60 \%$ of the observer team in any given AUEOM. The political and diplomatic component of an AU mission is made up of members of parliament from the Pan African Parliament and members of the permanent representative committee. This group constitutes the remaining $40 \%$ of observers in any mission. It needs to be noted that the blend of diplomats and politicians does not in any way reduce the technical imperatives. This is because for each mission, a three-day orientation and training programme on election observation methodology, observer code of conduct and the use of a checklist is organised. This is to ensure that all observers have the same level of knowledge about the AU's election observation procedures.

\section{Methodological Shift: From Short- to Long-term Mission}

The Durban Declaration on Democratic Elections in Africa and the African Union Guidelines for Elections Observation in Africa discussed above envisaged the early deployment of AUEOMs. In other words, they endorsed long-term election observation, although its operationalisation was belated. Thus, from 1989, when the continental election observation started, OAU missions were generally short-term. Usually OAU observers were deployed a few days prior to election day and left immediately after closure and counting. With this approach the AUEOM reports were unable to analyse more deeply the important events in the lead-up to election day - such as constituency demarcation, voter and candidate registration, and post-election dispute settlement. One of the major criticisms against the AUEOMs since their inception has been an inability to strike a balance 
between technical imperatives and political exigency. In fact, the AU was accused of lacking an appropriate data collection methodology to analyse election results in line with international standards and best practices. This led to calls from both internal and external stakeholders for the adoption of the long-term election observation methodology.

For instance, in 2010 the AU Panel of the Wise's Report on Election-Related Disputes and Political Violence (AU 2010), recommended that all stages of elections should be properly and effectively observed (pre-voting, voting and post-voting stages), and a comprehensive report on how the electoral processes were conducted should be prepared and submitted to the AUC and African public. The implication of this recommendation was the need for a methodological shift by the AU from short-term to long-term election observation. In practice, this is to allow the AUEOMs to pay attention to all stages of the electoral cycle, which include pre-electoral, electoral and post-electoral activities. The African Union Peace and Security Council reinforced this position during the 2012 briefings by the DPA on elections in Africa, and called for a more comprehensive approach to AU election observation. To give meaning to this request, the DEAU, with support from the UNDP, contracted a consultant to develop a new methodology to facilitate the inclusion of long-term observer (LTO) methodology in the AUEOM. This new methodology was adopted in May 2013 in Johannesburg, South Africa, paving the way for its official acceptance in AU missions.

The LTO experience of the AU was launched in Kenya from 15 January to 15 March 2013. Since this Kenyan period, AU LTOs have been deployed in Zimbabwe, Mali, Guinea, Madagascar, Guinea Bissau and Malawi. The AU has continued to prioritise LTO in its deployments, most recently to Mozambique and Tunisia in last quarter of 2014. This methodological shift has come with the need for the AU to build the capacity of prospective LTO observers and create a roster and database where details of trained long-term observers and experts will be stored and managed.

The first training for LTOs took place in May 2013 and included 20 prospective observers. The selection for LTOs differs significantly from the previous way in which AU observers were chosen, which was based on political and diplomatic importance. The observers were carefully selected after an open call for application, which was followed by shortlisting and training. Thus observers deployed in the pilot countries received training from the AU with support from the European Union (EU). However, the AU has subsequently started training prospective long-term observers, and to date has conducted four trainings for LTOs and election and legal analysts. This new approach confirms the AU's shift from a diplomatic to a more technical and independent mission. Their reports 
and conclusions are based on evidence from data generated by LTOs who have been deployed in the country for at least six weeks prior to election day.

\section{ILLUMINATING AU PROGRESS ON DEMOCRACY AND ELECTION OBSERVATION}

To properly illuminate the progress made by the AU in recent times, it is important to examine the organisation's work in the area of election observation from both a normative and a practical standpoint. According to Abbink and Hesseling (2000), the various policies and instruments that promote democracy and election observation in Africa lend themselves to various interpretations by different schools of thought. The procedural school of thought argues that normative instruments serve to proffer the solution and close the gap between election as a concept and election as a process. In their view, the normative framework provides the groundwork for procedural adherence. The participatory, substantive and institutional schools respectively argue that the AU instruments on democracy and election acted as a springboard for multiparty elections in Africa (Abbink \& Hesseling 2000, pp. 22-26). In essence the development of AU instruments on democracy and election represent an important progress in AU election observation.

As discussed in the previous sections, the AU's progress in defining its norms, principles and values underscores the slow yet consistent and incremental progress of African democracy since the late 1990s. Prior to the development of these instruments, the OAU was left in a state that could best be described as identity struggle. This is primarily because on the one hand, many African countries had gained independence, thus paving the way for democratic transition and democratisation. On the other hand, some countries were still in the clutches of colonisation, apartheid and occupation. Therefore, the OAU was faced with the struggle between challenging colonial rule and the democratisation of Africa. What constituted democratic ideals, values and principles in Africa at that time was not entirely clear to the Union, especially when some of the countries were still governed by undemocratic regimes. Therefore, discussions and debate on democracy were rarely the focus of discourse in a union where heads of states came to power undemocratically. Accordingly, we argue that the development of a normative base amongst difficult dictatorial and military regimes does constitute both achievement and progress.

Indeed, the normative instruments provided the basis upon which the AU would later demand assessment, through election observation, in order to ensure continual improvement in democratic principles and values in Africa. In short, the OAU could not have effectively observed elections within the context of prevailing 
military regimes and unconstitutional changes in government in Africa at that period without these continental norms.

Combined, the AU normative progress discussed in the previous section sets the stage for an independent election observation mission. Certainly, the incremental progress in the development of the instruments also brought a continual reshaping of AUEOM methodology in line with the principles of the AU declarations and charters. However, the development of these instruments also created the space for waves of civic advocacy and engagement in several African countries, which added impetus to the demand for democratic change. In most countries that transited from military rule to democracy, there were several citizens' demands for change. Therefore, the change did not merely emerge as a result of AU sanctions, but rather through popular demand and agitation for democracy by several non-governmental organisations and civil society groups. These groups strive to hold their governments accountable and to remind the AU of its role in ensuring that instruments are respected by member states.

At the same time, other African initiatives on democracy and election were gaining ground and demanding a greater commitment from African states. In 2001, the New Partnership for Africa's Development (NEPAD), through its Democracy and Political Governance Initiative, compelled African leaders to commit to the promotion and protection of democracy and human rights in their respective countries by developing accountability and participatory governance standards at national and sub-regional levels (NEPAD 2001). In the next section, we further examine this progress from a practical and methodological perspective.

The transition of the AUEOM from a diplomatic mission to an independent mission, and from a short-term to a long-term mission, has no doubt had a positive effect in reshaping public and international perceptions of AU observation in the last decade. The various instruments of democracy and elections identified and explored above have enshrined the roles and responsibilities of the various institutions, stakeholders and authorities in strengthening electoral processes and practices towards democratisation in Africa. However, not much has been done to ensure that member states adhere to those principles and guidelines. Table 1 shows an overview of elections observed by first the OAU and subsequently the AU between 1989 and 2013. This is followed by an in-depth discussion of the practical progress that has been made in terms of improving the quality of election observation missions in the continent by the African Union.

When the OAU / AU started observing elections on the continent, it struggled to operationalise its mandate and mission, and these challenges manifested in different forms. Firstly, as a union, the organisation failed to reconcile whether it needed a unified mission or a divergent mission. It had two parallel missions, one from the commission and the other from the Pan-African Parliament (PAP). Both 
Table 1

Election observation since 1989

\begin{tabular}{|c|c|c|c|c|c|}
\hline Year & Presidential & Legislative & General & Referendum & Total \\
\hline 1989 & & & & 1 & 1 \\
\hline 1990 & 2 & 3 & 2 & 3 & 10 \\
\hline 1991 & 4 & 4 & 1 & 5 & 14 \\
\hline 1992 & 6 & 10 & 4 & 12 & 32 \\
\hline 1993 & 8 & 9 & 2 & 3 & 22 \\
\hline 1994 & 1 & 5 & 3 & 3 & 12 \\
\hline 1995 & 1 & 7 & 1 & 2 & 11 \\
\hline 1996 & 13 & 9 & 1 & 4 & 27 \\
\hline 1997 & 3 & 7 & 2 & 1 & 13 \\
\hline 1998 & 4 & 7 & 1 & 1 & 13 \\
\hline 1999 & 5 & 8 & 3 & 1 & 17 \\
\hline 2000 & 4 & 5 & 2 & 3 & 14 \\
\hline 2001 & 8 & 5 & 1 & 5 & 19 \\
\hline 2002 & 5 & 12 & 2 & 1 & 20 \\
\hline 2003 & 6 & 5 & 0 & 1 & 12 \\
\hline 2004 & 3 & 8 & 2 & 0 & 13 \\
\hline 2005 & 5 & 6 & 3 & 5 & 19 \\
\hline 2006 & 8 & 4 & 3 & 1 & 16 \\
\hline 2007 & 5 & 12 & 4 & 2 & 23 \\
\hline 2008 & 2 & 7 & 0 & 0 & 9 \\
\hline 2009 & 13 & 11 & 0 & 0 & 24 \\
\hline 2010 & 8 & 8 & 0 & 2 & 18 \\
\hline 2011 & 14 & 14 & 1 & 1 & 30 \\
\hline 2012 & 6 & 12 & 1 & 0 & 19 \\
\hline 2013 & 2 & 10 & 2 & 1 & 15 \\
\hline Total & 131 & 176 & 37 & 55 & 423 \\
\hline
\end{tabular}

Source: Authors' table based on records of elections conducted in African from 1989 to 2013. 
the AUC and PAP were deploying their own missions with almost completely different approaches and methodology. While the AUC mission was composed mostly of CSOs and diplomats, the PAP mission was composed entirely of PAP Members of Parliaments (MPs). The implication was that the AUC mission, although political and diplomatic in nature, tried to consider technical aspects of election observation. Conversely, the PAP mission viewed observation as a parliamentary decision, and hence the decision on whether or not an election was credible depended on the number of its supporters. It was, in fact, treated as a parliamentary vote.

The two missions also operated in silos, with neither operational nor coordination communication. They were critical of each other, with mutual accusations about lacking an observation methodology. An example is the different statements made in the aftermath of the 2008 elections in Zimbabwe. This division and lack of synergy between the two AU missions led to an internal decision to merge the two missions into one. This in essence solved the unified mission problem - and is considered in this paper as progress in practical and operations terms.

The second issue was the capacity to move from being a diplomatic to an independent technical mission. This relates directly to converting the declarations and principles into actionable directives in practical terms. Essentially, the AU in its early stages struggled with the methodology and practical process of deployment and the management of missions. This was especially so in ensuring that AU instruments were applied in the deployment, coordination and release of AUEOM reports. The AU struggled to interpret its mandate and ensure that the various clauses in the mandate were implemented in every mission. For instance, the AU does not possess any roster of professionally trained analysts from which it could recruit observers. However, since 2013 the Democracy and Electoral Assistance Unit (DEAU) has started the training of professional long-term observers and analysts as a way of filling the gap and continuing in its transition trajectory.

There was also gap in the release of the report for public use and the legitimisation of the AU mission. Although Section V1 (g) of the Durban Declaration on the Principles Governing Democratic Election in Africa clearly states that the AUC should release the AUEOM reports for public consumption, such provision eluded the commission until November 2012. The commission then adhered to the provision and began publishing AUEOM reports for public use on the AUC website. This decision not only filled the missing gap in terms of public demand but also raised the status of the AUEOMs. In addition, it created the opportunity for public engagement with the report and for development of the means to ensure that recommendations of such reports are implemented before the next election. 
The transition from short-term to long-term mission was a result of the accompanied expansion required to ensure comprehensive methodological and procedural transition. This expansion includes the training of observers; the publication of a manual, guidelines and handbooks; and the development and design of observation rosters and of a database. An important step forward in this transition from short-term to long-term was the development of a professional roster. Prior to the adoption of the long-term framework and methodology, the selection of AU observers was carried out in an ad hoc manner without clearly defined criteria for selection. Observer selection was based on political and social capital rather than on professional and expert experience. With the adoption of the long-term approach, the AUC developed a clean roster where details of fully trained observers are stored and retrieved when required for mission. This roster also contains space for experts in different areas of election analysis to be trained and maintained for use in any AU mission. The new roster is accompanied by the training of AU long-term observers and experts. In addition to this training, the DEAU has developed a curriculum for training LTOs and experts. Since the development of these important elements of AU mission, the DEAU has conducted several training courses to build capacities of Africans as election, legal, conflict, medial and minority experts. One important objective and element is that the trained LTOs and experts will constitute a database of African experts on elections who can subsequently be used as experts, LTOs and trainers.

A closely related area of improvement was the development of new tools and methodology for election day observation. The DEAU has made improvements in the redesign and redevelopment of its election-day observation checklist in order to improve its data collection and analysis.

Importantly, the AU has also moved to ensure that AUEOM report recommendations are implemented by member states by developing a strategy for implementing these recommendations. This strategy is currently in its pilot stage, after which the AUC will evaluate and escalate the project to many other countries. ${ }^{7}$ The strategy is linked to the AU electoral assistance programme. In essence the $\mathrm{AU}$ will determine the direction and nature of its electoral assistance by ensuring that countries properly consider AUEOM recommendations when requesting assistance.

In summary, with the new long-term methodology, observers are recruited transparently and professionally. This is possible with the training of new observers and experts as well as the design of the roster and database. The selection of observers and experts is henceforth mainly from the roster of trained

7 DEAU is working with the Malawi Electoral Commission on implementing the AUEOM report recommendations for 2014 . 
experts and observers. In addition, the new long-term methodology provides for a longer-term approach where AU long-term observers are deployed six weeks prior to election day and two weeks thereafter. This is clearly in line with other international practices like the European Union election observation missions (EU 2009).

In the next section, we examine the additional steps required for the AU to ensure that its mission is fully technical, professional and independent. This is to ensure that data generated across the different stages of the election process forms the basis of analysis and conclusion.

\section{WHAT LIES BEYOND: THE MISSING LINKS}

In term of looking beyond the current situation, it is crucial that the AU builds on existing progress by ensuring that the AUEOM is professionalised and fully independent. The AU has conducted several elections in the past, and one criticism against it is that it has failed to maximise its potential as the continental body. In most cases, the level of analysis and the methodological rigour have been questioned. It is imperative that the AU continue its development to ensure consistent and continuous improvement in its methodology, approach and analysis in a way that not only conforms to international standards and best practices but also shows respect for its own normative frameworks.

One way of establishing this is to ensure that the long-term framework is fully translated into practical actions. This would require continual training of potential long-term observers and experts as well as ensuring that trained LTOs and experts are utilised in different missions. The advantage is that the AU can subsequently ensure that the roster of observers for selection consists exclusively of fully trained experts. They should be capable of interpreting and analysing AU instruments and norms on elections but also work to ensure full implementation of the long-term framework. This means that the new sets of LTOs and experts would be considered as a pioneer resource for the full implementation of the AU LTO framework. This will also ensure that the AU, through the DEAU, positions itself to ensure the continual upgrade of the election database and roster in a sustainable manner. It is important that while the AU is improving its election observation methodology, there should be a benchmark by which it measures its own improvement.

The development of a clear communication strategy for the AU mission is also important. Over and above the development of such a strategy, the new AU framework must be adequately communicated and disseminated to all relevant stakeholders to ensure compliance with - and the legitimacy of - the instrument. This requires communicating the methodological changes to the current and 
prospective heads of missions in a way that ensures comprehensive understanding of the objective of the new long-term methodology and the role expected of the mission leaders. An annual consultative retreat for heads of missions and prospective heads of mission would serve this purpose effectively. Within this context, the AU can thus review the changes on the mission from a technical angle. This would also ensure that new entrants would be fully briefed on both the technical imperatives and political exigency of an AU mission. An important tool to ensure such understanding is the development of a head of mission aidememoire. This would eventually bridge the gap between the technical imperative and political exigency by ensuring that heads of missions understand both the technical needs of the mission and the limits of political considerations.

Consideration should also be given to the need to ensure continuous capacitation of the DEAU, which is responsible for the planning, coordination and management of the AUEOMs. While the need for training observers and experts was highlighted in the previous paragraphs, it is far more crucial that the capacity of the staff responsible for running the entire process of election observation in the AU be developed. Putting the new long-term framework into perspective, the full implementation of this new framework requires improved capacity of the personnel within the DEAU in qualified and quantitative terms. This is of considerable importance if the DEAU begins the deployment of core teams to its LTO missions. Therefore, given the work level with the DEAU and the imperative to observe all national elections in Africa, it is important that the AU should think beyond the current state of affairs within DEAU and ensure that plans for incremental improvement in its human capacity are included in its long-term planning.

While the DEAU is currently deploying LTO, an urgent decision is required on the deployment of core teams. The AU's move to long-term observation would require a dedicated core team on the ground for every long-term mission. The core team should include trained experts capable of analysing the different aspects of the elections and of presenting a credible report to the AU. For the sustainability of its long-term mission, the AU should develop an annual training plan for experts and core team members that DEAU would rely on for the quality and credibility of the mission. This also applies to the training and pooling of LTOs.

Under what condition does the AU send an LTO or STO Mission? What are the criteria for selecting a country for either of these missions? These are crucial questions that the AUC should answer internally in order to make the AU longterm mission purposeful and value-driven. Implementing the AU long-term framework therefore demands that a proper yardstick is developed to determine the following: (1) whether the AU should deploy a mission to a particular country, and (2) what type of mission should be deployed. A proper assessment in the 
form of either an exploratory mission or a pre-election assessment mission would be able to answer these questions. In addition, this could serve as a means to mitigating electoral violence because such data could identify potential triggers and indicators of electoral violence. This could be averted by the intervention of the AU before the election through the Office of the Chairperson or the Peace and Security Council of the AU.

Special attention should be devoted to ensuring that the AUEOM recommendations are implemented by member states before the next election. The AU has started an initiative on a follow-up to the implementation of observers' recommendation. A draft strategy has been in place since 2013. Therefore, the AU should ensure that the initial pilot cases form the basis for further escalation to ensure that AUEOM recommendations are implemented. From an optimistic point of view, the AU could use this strategy as a way of advocating for institutional and electoral reforms in member states in line with the African Union Charter on Democracy, Elections and Governance.

Building stronger relationships with the regional economic communities (RECs) such as ECOWAS and SADC is another important dimension. Such collaboration would take various forms and could be structured from a purely technical standpoint. Some of the collaborations could include working towards a continent-wide training curriculum on election observation, harmonising the various observation methodologies between the AUC and the RECs, and in particular working towards the adoption of the AU long-term methodology as a preferred continental methodology for election observation in Africa. Other areas could include structuring a formal process of sharing information and data between the AUC, RECS and CSOs during missions.

\section{CONCLUSION}

In this article we have considered how the AUEOM has evolved from diplomatic and political missions to independent and technical missions. While examining these changes, we identified that the most important change so far has been the shift away from short-term to long-term election observation missions based on an electoral cycle approach. While our analysis challenges the AU to take further steps to ensure that the AUEOM is fully professional and that reports are based on evidence generated over a period of time by trained observers and experts, we recognise that the AU election observation trajectory has been through different stages. These stages include the struggle for freedom, human rights and democracy within the context of apartheid and occupation - and in some cases colonialism; norm-setting in a democracy; anti-coup and unconstitutional change; and the regime of election observation as a means to confirming state 
compliance. Finally, the current regime is focused on professionalising the AUEOM and making it an independent technical mission.

In conclusion, we recognise that while the AU faces challenges in reaching its desired technical competence in terms of election observation, it also identifies areas of immediate short-term improvement. An important linkage is drawn between the AU as the continental body and the RECs. Although there are still gaps in the deployment of AU election observation, the sustainable consolidation of democracy and electoral transparency in Africa entails an appreciation of the democratic trajectory, identifying the gaps and accepting the need for improvement.

\section{- REFERENCES}

Abbink, J \& Hesselling, G 2000, Election observation and democratization in Africa, Palgrave Macmillan, London.

AU 2000, Constitutive Act of African Union, African Union, Addis Ababa: African Union viewed 16 February 2014. Available at: http://www.au.int//en/ sites/default/ files / ConstitutiveAct_EN.pdf.

AU 2002a, Guidelines for African Union electoral observation and monitoring missions, EX.CL/91 (V). Durban: African Union viewed 15 February 2014. Available at: http: / / www.au.int / / en/ sites / default / files / treaties / 7790-fileafrican_charter_on_democracy_elections_and_governance.pdf.

AU 2002b, Durban Declaration on Principles Governing Democratic Elections in Africa, AHG/Decl. 1 (XXXVIII), Durban: African Union.

AU 2007, African Charter on democracy, elections and governance, African Union, Addis Ababa: African Union, viewed 15 February 2014. Available at:

http:// www.au.int/en/sites/default/files/treaties/7790-file-african_charter_on_democracy_elections_and_governance.pdf.

AU / IPI 2010, Election related disputes and political violence, International Peace Institute/African Union, New York.

EU 2009, Handbook for European Union election observation, European Commission, Brussels.

Fayemi, AK 2009, 'Towards an African Theory of Democracy', Thought and Practice, vol. 1, no. 1, pp. 101-126.

ICG-M International Contact Group on Madagascar, viewed 16 February 2014 Available at: http://www.peaceau.org/uploads/communiquy-gic-madagascareng-26-06-2013-final.pdf.

OAU 1984, Decision of assembly of heads of state and government twentieth ordinary session Organisation of African Unity, Addis Ababa. 
OAU 1990, Declaration adopted on 11th July 1990, on the political and socioeconomic situation in Africa and the fundamental changes taking place in the world. Addis Ababa, Organisation of African Unity.

OAU 1997, Declarations and decisions adopted by the thirty-third assembly of heads of state and government, Organisation of African Unity, Harare.

OAU 1998, Ushering the OAU into the next century: a programme for reform and renewal, Organization of African Unity, Addis Ababa.

OAU 1999, OAU AHG/Dec.141 (XXXV), adopted during the Thirty-fifth Ordinary Session of Assembly, Organisation of African Unity, Algiers.

OAU 2000, OAU Lomé Declaration of July 2000 on the framework for an OAU response to unconstitutional changes of government (AHG/Decl.5 (XXXVI) Organisation of African Unity, Lome.

Souaré, IK 2009, The AU and the challenge of unconstitutional changes of government in Africa, ISS Paper 197, ISS, Addis Ababa.

Souaré, IK 2014, 'The African Union as a norm entrepreneur on military coups d'état in Africa (1952-2012): an empirical assessment', Journal of Modern African Studies, vol. 52, no. 1, pp. 69-94.

Tieku, TK 2009, 'Multilateralization of democracy promotion and defense in Africa', Africa Today, vol. 56, no. 2, pp. 74-91. 